\title{
Kvantitatívny pohl'ad na vplyv asymetrickej informácie na teóriu dôvery a teóriu reciprocity ${ }^{1}$
}

\section{On Quantitative Insight on the Impact of Asymmetric Information on the Theory of Trust and Reciprocity Theory}

\author{
Matúš Kubák, Vladimír Gazda, Zuzana Lejková, \\ Jozef Nemec
}

\begin{abstract}
Trust and reciprocity enter to the majority of personal, social and economic interactions. Cooperative behaviour can result to serious benefits to counterparts, while self-regarding, thus non-trusting and non-reciprocal engagement can result to harm. We present an investment game (trust experiment) with symmetric information and investment game with asymmetric information. We also implement belief elicitation of participants about the counterpart action. This allows us to document alongside motives of the participants' behaviour. We repeat experiment in five rounds and observe the impact of symmetric and asymmetric information on trust and reciprocity evolution. We observe deviations of economic agents from strictly rational and self-regarding preferences. Agents do not keep Nash equilibrium. We document direct evidence of the fact, that trust induces reciprocity. Participants are inequality averse and we observe subtly opportunistic behaviour in game with asymmetric information, where participants make use of informational disparity. Reputation effect was not confirmed, thus trust and reciprocity does not evolve in significant way during interaction. Also, step out effect was not confirmed, thus participants have no tendencies to defect from cooperation. Participants in our experiments are sending sums that are similar to sums in reference experiments. Anyway, Senders in Slovakia are sending sums that are smaller that sums sent in other countries. Senders are not inequality averse, thus do not believe that Receivers will send them sum that is fair distribution of profit from investment. Receivers in symmetric version of the experiment are more inequality averse than receivers in asymmetric version. Trust of participants increases with participants' expectations. We also observe also weak influence of previous rounds on behaviour of economic agent in present round. However, this influence is not statistically significant.
\end{abstract}

KEYWORDS Economic experiment, investment game, symmetric/asymmetric information, trust

Sociální studia. Katedra sociologie FSS MU, 4/2015. S. 31-56. ISSN 1214-813X.

1 Výskum bol podporený projektom VEGA 1/0726/14 „Experimentálne skúmanie tendencií ekonomických agentov ku korupcii“. 


\section{Úvod}

Nasledujúci experiment bol inšpirovaný experimentmi Dôvera, reciprocita a sociálna história (Berg et al. 1995) a Investičná hra s asymetrickou informáciou (Coricelli et al. 2006). Predkladaný experiment bol rozšírený o možnost' sledovania efektu reputácie, efektu učenia sa a step out efektu. Taktiež prispieva k chápaniu vplyvu asymetrickej informácie v dlhšej perspektivite budovania reputácie a dôvery. Prínosom experimentu je aj interpretácia výsledkov vo vzt'ahu k podobným experimentom.

Investičná hra a jej chápanie dôvery sú v ostatnom desat'ročí využívané na štúdium behaviorálych odchýlok od racionality. Fukuyama (1996) uvádza, že dôvera medzi l’ud'mi je sociálny kapitál, ktorý je hlavným faktorom ekonomického rozvoja (Fukuyama Conjecture). Táto domnienka je experimentálne podložená (Ahmed a Salas 2008; Holm a Danielson 2005). Csukás et al. (2008) vykonali porovnanie dôvery vo viacerých krajinách. Výsledky experimentu poukazujú na fakt, že rozdiely v kultúre a v stupni ekonomického vývoja sú faktory, ktoré pôsobia na úroveň medzil'udskej dôvery.

Deduktívne teórie dôvery sa zameriavajú na opísanie rozdielov medzi racionálnym správaním sa a sebeckými preferenciami, ktorých koncepty vychádzajú z teórie hier a preferenciami zohl'adňujúcimi blaho iných (Fehr a Schmidt 1999; Cox et al. 2008). Dôvodom je existencia altruistických motívov a reciprocity v prejavoch l'udského správania sa. Rozdiel medzi reciprocitou a altruizmom spočíva na reakcii druhej strany interakcie. V prípade altruizmu nie je pozitívna reakcia na akciu závislá od samotnej akcie. V prípade reciprocity však reakcia závislá od akcie je. Existuje pozitívna a negatívna reciprocita. V prípade pozitívnej reciprocity ide o odmeňovanie pozitívnej akcie, kým v prípade negatívnej reciprocity hovoríme o trestaní akcií nesúcich v sebe známky zloprajnosti a egoizmu. Akceptujúc Fukuyamov dohad o dôležitosti dôvery v ekonomickom rozvoji sa mnoho autorov snaží identifikovat' faktory ovplyvňujúce dôveru.

Štúdium týchto faktorov sa stalo predmetom interdisciplinárnych štúdií (Cox a Deck 2006; Greig a Bohnet 2005 atd’.). Fershtman a Gneezy (2001) poukázali na vplyv etnického pôvodu na výsledky investičnej hry. Vplyv komunikácie medzi hráčmi pred začatím experimentu na jeho výsledok opísali Ben-Ner a Putterman (2009). Coricelli et al. (2006) a Engelmann a Fischbacher (2009) opísali vplyv informačnej úrovne na výsledky investičnej hry. Takahashi et al. (2006) dokázali vplyv fyzickej atraktivity na dôveru a kooperáciu. Gróf et al. (2012) skúmali vývoj dôvery a kooperácie v zložitejších štruktúrach štruktúrach. Cesarini et al. (2008) skúmali heritabilitu dôvery na jednovaječných a dvojvaječných dvojčatách. Poukázali na fakt, že l'udia majú rozdielne genetické danosti v spojitosti s investovaním a reciprocitou. Kosfeld et al. (2005) dokázali vplyv hormónu oxytocín na doverčivost' l'udí v investičnej hre. Stanton (2009) poukázala na vplyv oxytocínu a antidiuretického hormónu na kooperáciu. Johnson a Mislin (2011) vykonali komplexnú metaanalýzu obsahujúcu údaje zo 162 experimentov, ktoré replikovali experiment Berg et al. (1995). Autori pracovali s databázou, ktorá obsahovala informácie o viac ako 23000 subjektoch. Sledovali, ako na výsledky experimentu vplýva výška finančného zisku za experiment, anonymita experimentu, menenie rôl účastníkov počas experimentu, to, či sú účastníci eperimentu študenti, alebo nie sú, či hrajú proti reálnemu človeku, ako vplýva geografická lokalizácia a etnikum na výsledok experimentu, a iné. Štúdia poukázala na fakt, že ak je na 
konci experimentu vyplatený len jeden participant, alebo len niektorí participanti, tak subjekty si v investičnej hre zasielajú signifikantne nižšie sumy. Experimenty d’alej poukázali na fakt, že v Afrike sú l'udia menej dôverčiví ako na ostatných kontinentoch. V Severnej Amerike je to naopak. Autori d’alej poukazujú na skutočnost', že obojstranná anonymita nemá žiaden vplyv na sumy zasielané v priebehu experimentu. Zaujímavým je aj zistenie, že počiatočný rozpočet subjektov nemá žiaden vplyv na zasielané sumy (tieto rozpočty sa pohybovali vo výške od $0 \$$ do 238 \$). Jeden z najrobustnejších záverov Johnsona a Mislinovej (2011) je ten fakt, že ked' experimentátori znížia multiplikátor z hodnoty 3 na hodnotu 2, tak suma zaslaná spät’ receiverom sa zníži o menej ako jednu tretinu. Čo sa týka dôveryhodnosti subjektov, platí, že študenti zasielajú spät' sumy nižšie ako subjekty, ktoré študentmi nie sú. Závery meta-analýzy taktiež indikujú, že malé zmeny v protokole experimentov rezultujú do značných posunov v dôvere. Subjekty v roli receiverov zasielajú spät’ nižšie sumy, ak je multiplikátor nízky a ak sú subjekty študentmi.

\section{Dizajn experimentu}

Účastníci experimentu sú náhodne spárovaní. Dvoch účastníkov, ktorí vstupujú do interakcie, nazývame účastník $X$ a účastník $Y$. Účastníci $X$ sú na t’ahu prví (senderi, first moveri) a účastníci $Y$ sú na t’ahu druhí (receiveri, second moveri). Každý z účastníkov experimentu, $X$ aj $Y$, dostáva na začiatku 100 experimentálnych peňažných jednotiek (EPJ). Túto počiatočnú dotáciu peňažných jednotiek označujeme $\omega$. Účastník $X$ posiela účastníkovi $Y$ zo svojich 100 $E P J$ l'ubovol'nú čiastku, ktorú nazývame suma $a$. Pre sumu $a$ platí: $0 \leq a \leq \omega$. Suma $a$, ktorú účastník $X$ poslal účastníkovi $Y$, je následne účastníkovi $Y$ prenásobená multiplikátorom $m$, ktorý nadobúda hodnotu $m=3$ vo verzii experimentu so symetrickou informáciou a hodnotu $m=2$ alebo $m=4 \mathrm{v}$ asymetrickej verzii experimentu. $\mathrm{V}$ asymetrickej verzii experimentu nadobúda multiplikátor $m$ hodnotu $m=2 \mathrm{~s}$ pravdepodobnost'ou $p \in(0,1)$ a hodnotu $m=4$ s pravdepodobnost'ou $(1-p)$. Hodnota pravdepodobnosti $p$ je generovaná náhodne počítačom. Iba účastník $Y$ pozná ozajstnú hodnotu multiplikátora. Tu je moment, v ktorom dochádza k asymetrii informácie a možnosti oportunistického správania sa, nakol'ko účastník $Y$ má po prenásobení sumy $a$ multiplikátorom $m \mathrm{k}$ dispozícii sumu peňažných jednotiek, pre ktorú platí: $m * a+\omega$. Na t’ahu je teraz účastník $Y$, ktorý posiela účastníkovi $X$ sumu $b$, pre ktorú platí: $0 \leq b \leq m * a+\omega$. Oportunistické správanie sa nastáva vtedy, ak účastník $Y$ predstiera, že mu boli finančné prostriedky, ktoré poslal účastník $X$, prenásobené multiplikátorom $m=2$, aj ked' mu v skutočnosti boli finančné prostriedky, ktoré poslal účastník $X$, prenásobené multiplikátorom $m=4$. Iba účastník $Y$ si je vedomý skutočného zhodnotenia investície v podobe sumy $a$, ktorú mu poslal účastník $X$.

Na t’ahu je teraz účastník $Y$, ktorý posiela účastníkovi $X$ sumu $b$, pre ktorú platí:

$$
0 \leq b \leq m * a+\omega \text {. }
$$

Účastníci experimentu boli vyzvaní aj k zaznamenaniu svojho odhadu ohl'adom sumy, ktorú im pošle druhý člen dvojice. To znamená, že účastník $X$ robí odhad ohl'adom sumy $b$, ktorú mu pošle účastník $B$ spät'. Formálne zapisujeme odhad sumy, ktorú očakáva hráč $X$ od hráča 
$Y E_{X}(b)$. Ak platí $E_{X}(b) \geq a$, hovoríme, že účastník $X$ verí účastníkovi $Y$. Účastník $Y$ robí odhad ohl'adom sumy, ktorú mu pošle účastník $X$. Formálne zapisujeme tento odhad $E_{Y}(a)$. Tieto odhady súm, ktoré mali účastníci vykonat', sú podkladom na skúmanie teórie dôvery medzi účastníkmi experimentu.

Teoretickým východiskom a riešením hry je $a=0$ pre účastníka $X$, nakol'ko tento je neobmedzene racionálny a nemal by verit’ účastníkovi Y a $b(a)=0$ pre účastníka $Y$, ako reakcia na nulovú sumu, ktorú zaslal účastník X.

Model kola experimentu je zobrazený na Schéme 1.

Schéma 1: Schéma experimentu

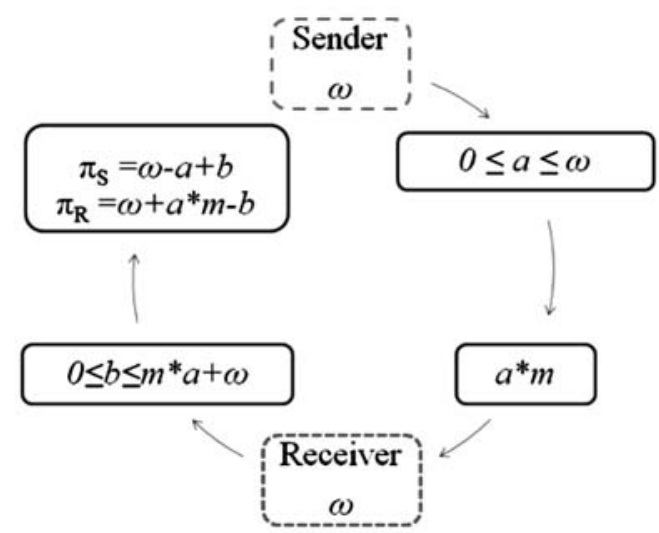

\section{Štruktúra experimentu}

Experimentu sa zúčastnilo 136 subjektov, z čoho 98 bolo žien a 38 mužov. Subjekty tvorili študenti Technickej Univerzity v Košiciach a Ekonomickej Univerzity v Bratislave. Experimentu so symetrickou informáciou sa zúčastnilo 70 subjektov a experimentu s asymetrickou informáciou sa zúčastnilo 66 subjektov. Priemerný vek študentov bol 22 rokov. Subjekty sa nikdy predtým nezúčastnili obdobného ekonomického experimentu. Experimenty riadili vždy tí istí traja experimentátori, z dôvodu eliminovania ovplyvnenia výsledkov experimentu l'udským faktorom. Experiment prebehol v ôsmych zmenách, pričom počas štyroch zmien bol odohraný experiment so symetrickou informáciou a v ostatných štyroch zmenách bol odohraný experiment s asymetrickou informáciou. Počet účastníkov experimentu v jednotlivých zmenách bol vyrovnaný.

Po príchode do miestnosti si účastníci experimentu losovali role, ktoré mali počas experimentu zastávat' (senderi a receiveri). Následne boli hráči náhodne a anonymne spárovaní. Páry sa počas experimentu nemenili. Hráči na seba v miestnosti videli, ale nevedeli, s kým sú spárovaní. Účastníkom experimentu teda bolo jasné, že sú spárovaní s reálnym človekom. Po vylosovaní si rolí boli účastníci experimentu vyzvaní, aby sa usadili v laviciach, a boli im rozdané inštrukcie. Účastníci experimentu mali 15 minút na prečítanie si inštrukcií. Potom boli vyzvaní, aby sa v prípade nejasností opýtali inštruktorov, čo im nie je 
jasné. Po zodpovedaní otázok bol experiment zahájený. Všetkým subjektom bol na začiatku experimentu pridelený rozpočet 100 EPJ (v každom kole bol rozpočet obnovovaný). Výška počiatočného rozpočtu bola známa všetkým hráčom.

Experiment pozostával z 5 kôl, to však subjekty pred odohraním prvého kola nevedeli. Po odohratí prvého kola bolo účastníkom povedané, že budú nasledovat' d’alšie kolá a že sú spárovaný stále s tým istým partnerom. Celkový počet kôl nebol hráčom vopred indikovaný. V každom kole bol počiatočný rozpočet respondentov nastavený na 100 experimentálnych peňažných jednotiek (EPJ). Nemennost' dvojíc a opakovanie kôl boli zámerné. Pred posledným, piatym kolom experimentu, boli hráči upovedomení o tom, že ide o posledné kolo experimentu. Vd'aka takto navrhnutému experimentu bolo možné sledovat' learning effect, vytváranie reputácie, vzt’ahu dvojice hráčov a step out effect - nedôvera senderov, resp. zbehnutie z kooperácie receivermi v poslednom kole.

Hráči hrali prvé kolo experimentu ako one shot hru, to znamená, že nevedeli, že budú nasledovat' d’alšie štyri kolá. To umožnilo experimentátorom porovnávat' získané údaje s údajmi iných autorov, ktorých údaje boli z one shot hier, a zároveň skúmat' efekt reputácie, step out efekt a efekt učenia sa. V každom kole bol hráčom nastavený iniciálny rozpočet na úroveň 100 EPJ a počas trvania experimentu hrali hráči v tých istých dvojiciach. Úlohy $\mathrm{v}$ dvojiciach sa tak isto nemenili. Experiment pozostával z piatich kôl. Pred posledným kolom bolo hráčom oznámené, že pôjde o posledné kolo.

V prvej fáze experimentu senderi zaznamenali na hraciu kartu sumu $a$, ktorú sa rozhodli poslat' receiverovi. ${ }^{2} \mathrm{~V}$ tom čase receiveri vyplńali na svojich kartách odhad sumy, ktorú im pošle sender $E_{Y}(a)$. Potom boli hráčom karty zozbierané a riadiaci experimentu vyrátali disponibilné sumy receiverov (počiatočný rozpočet $\omega+m * a$, v symetrickej verzii hry $m=3$, v asymetrickej verzii hry $m=2$, alebo $m=4$ ). Potom boli hráčom rozdané karty a začala sa druhá fáza experimentu, v ktorej sa receiveri rozhodovali, kol'ko pošlú spät' senderom. Senderi v druhej fáze robili odhad sumy $b E_{X}(b)$, ktorú im pošle receiver spät'. Nakoniec experimentátori znova zozbierali hracie karty a vypočítali finálne zisky subjektov. Finálne zisky boli oznámené subjektom anonymne. Hracie karty obsahovali kontrolné otázky, pomocou ktorých bolo možné identifikovat' subjekty, ktoré neporozumeli dizajnu experimentu správne. Takéto údaje boli z analýzy odstránené. To je dôvod, prečo máme pre symetrickú verziu hry 70 pozorovaní a pre asymetrickú verziu hry 66 pozorovaní.

Experimentálne peňažné jednotky boli po experimente hráčom zamenené za reálne peniaze. Subjektom bolo počas experimentu dôrazne vysvetlené, že budú vyplácaní všetci účastníci experimentu a za všetky kolá. V priemere si študenti zarobili $6,95 €$ per capita.

\section{Hypotézy}

Hypotéza 1: Suma $a=0 \&$ suma $b=0 .(b(a)=0)$ pre všetky a $[0, \omega]$.

Táto hypotéza je zameraná na racionálne správanie sa a vychádza z teoretického východiska a riešenia hry, kedy je $a=0$ pre účastníka $X$ a $b(a)=0$ pre účastníka $Y$.

2 Hracie karty tvoria prílohu tejto štúdie. 
Hypotéza 2: $A k E_{X}(b) \geq a$, potom $a>0 ; \& a k\left(a-E_{Y}(a)>0\right)$, potom $b \geq a$.

Táto hypotéza sa snaží dokázat', že medzi účastníkmi experimentu dochádza ku kooperácii, ktorá je založená na dôvere, reciprocite a averzii k nerovnosti.

Hypotéza 3: Sumy a \& b, ktoré si navzájom účastníci X a Y posielajú, sú pozitívne korelované. Táto hypotéza je zameraná na dokázanie kooperácie medzi hráčmi.

Hypotéza 4: Suma b, ktorú posiela účastník $Y$ spät účastníkovi $X$, je rovnaká pre $m=2$ $\& m=4$.

Táto hypotéza je zameraná na oportunistické správanie sa zo strany receiverov. Cielom hypotézy je skúmanie vplyvu asymetrickej informácie na konanie hráčov v investičnej hre.

Hypotéza 5: Pre sumy, ktoré posiela hráč $X v$ prvých štyroch kolách experimentu, platí $a_{1}<a_{2}<a_{3}<a_{4}$ a pre sumy, ktoré posiela hráč $Y$ v prvých štyroch kolách spät hráčovi $X$, plati $b_{1}<b_{2}<b_{3}<b_{4}$.

Táto hypotéza sa snaží dokázat', že s opakovaním experimentu dochádza k vytvoreniu reputácie medzi hráčmi vo dvojici.

Hypotéza 6: Suma $a_{5}$ poslaná hráčom X hráčovi Y v piatom (poslednom) kole je menšia ako suma $a_{4}$ poslaná hráčom $X$ hráčovi $Y$ vo štvrtom kole. Suma $b_{5}$ poslaná hráčom $Y$ hráčovi $X$ spät'v piatom (poslednom) kole je rovná nule.

Hypotéza 6 je zameraná na sledovanie step out effectu, kedy hráč X vie, že ide o posledné kolo experimentu, a teda predpokladá, že mu hráč Y zašle spät' nula EPJ, nakol'ko hráč Y by mohol oportunisticky zbehnút' z vytvorenej relácie dôvery.

Hypotéza 7: Sumy a \& b, ktoré si hráči posielajú v jednotlivých kolách, sú rovnaké pre symetrickú verziu hry aj asymetrickú verziu experimentu.

Hypotéza 7 overuje škodlivost' asymetrickej informácie na dôveru a dôveryhodnost' ekonomických agentov.

\section{Výsledky experimentu}

Tabul'ka 1 sumarizuje výsledky experimentov vykonaných v USA (Berg et al. 1995; Cox 2004), Švédsku (Holm a Danielson 2005), Tanzánii (Holm a Danielson 2005) a na Slovensku (zo Slovenského experimentu je uvedené prvé kolo). V tabul'ke sa nachádzajú základné charakteristiky senderov a receiverov. 
Tabul'ka 1: Porovnanie Slovenského experimentu s referenčnými zahraničnými experimentmi

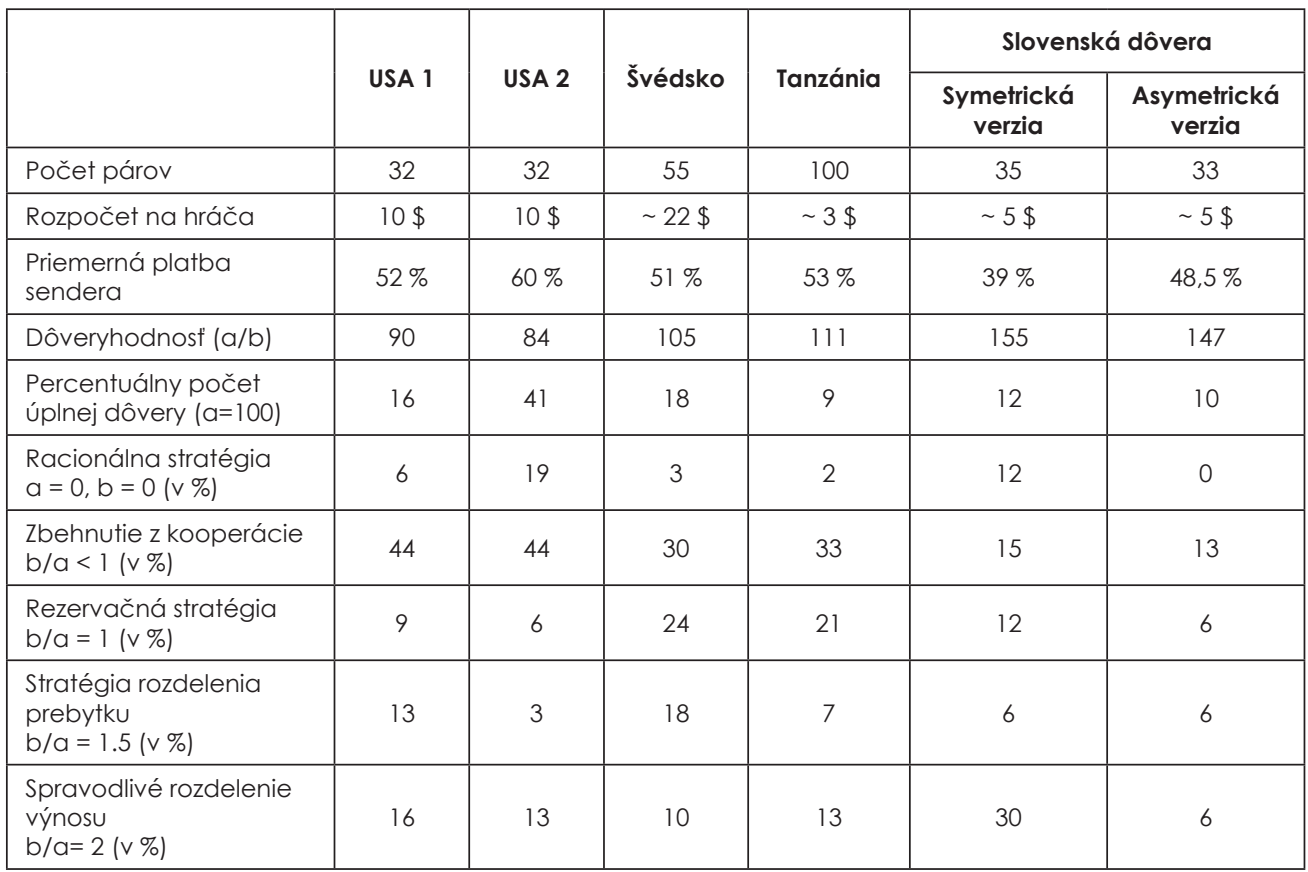

Tabul'ka 1 rozoznáva základné stratégie hrané sendermi a receivermi, tzv. fokálne stratégie. V tabul'ke sa nachádzajú iba platby z prvého kola experimentu $\mathrm{z}$ dôvodu porovnatel'nosti údajov a odstránenia možných vplyvov efektu reputácie, step out efektu a efektu učenia sa. Zaujímavost'ou je, že dôvera senderov na Slovensku je najnižšia v porovnaní s nami uvažovanými experimentmi. Avšak, ak berieme do úvahy v úvode zmieňovanú meta-analýzu Johnsona a Mislinovej (2011) pozostávajúcu zo 162 experimentov, tak je platba senderov v symetrickej verzii hry priemernou platbou. Zaujímavým zistením v našom experimente je fakt, že dôvera $v$ asymetrickej verzii hry je vyššia, ako dôvera v symetrickej verzii hry. Výrazný je aj rozdiel v dôveryhodnosti receiverov na Slovensku. Receiveri na Slovensku zasielajú senderom spät' v priemere viac experimentálnych peňažných jednotiek, ako receiveri z iných krajín. Svetový priemer je na úrovni 90 \%, čiže receiveri na Slovensku sú výrazne dôveryhodnejší, ako receiveri z ostatných štúdií vykonaných celosvetovo (Johnson a Mislin 2011). Zaujímavost'ou je aj fakt, že na Slovensku v prvom kole asymetrickej verzie investičnej hry nehral racionálnu stratégiu ani jeden sender. V slovenskom experimente sa vyskytuje najčastejšie zbehnutie z kooperácie, zrada, kedy b/a $<1 \mathrm{v}$ porovnaní s referenčnými experimentmi. Zaujímavý je aj fakt, že v symetrickej verzii slovenského experimentu sa najčastejšie vyskytuje spravodlivé rozdelenie výnosu z investície. 
Hypotéza 1 : Suma $a=0$ \& suma $b=0 .(b(a)=0)$ pre všetky $a[0, \omega]$.

Priemerná suma, ktorú posielajú senderi v symetrickej verzii hry, je v prvom kole 38 EPJ a priemerná suma, ktorú zasielajú receiveri spät', je v symetrickej verzii 60,57 EPJ. Priemerná suma, ktorú posielajú senderi v asymetrickej verzii hry, je v prvom kole 48,48 EPJ a priemerná suma, ktorú zasielajú receiveri spät’ v asymetrickej verzii hry, je 66,8 EPJ.

Obrázok 1 znázorňuje histogram zaslaných súm sendermi v symetrickej verzii. Z 35 subjektov len štyri zaslali $a=0$.

Obrázok 1: Histogram súm zaslaných sendermi v symetrickej verzii hry

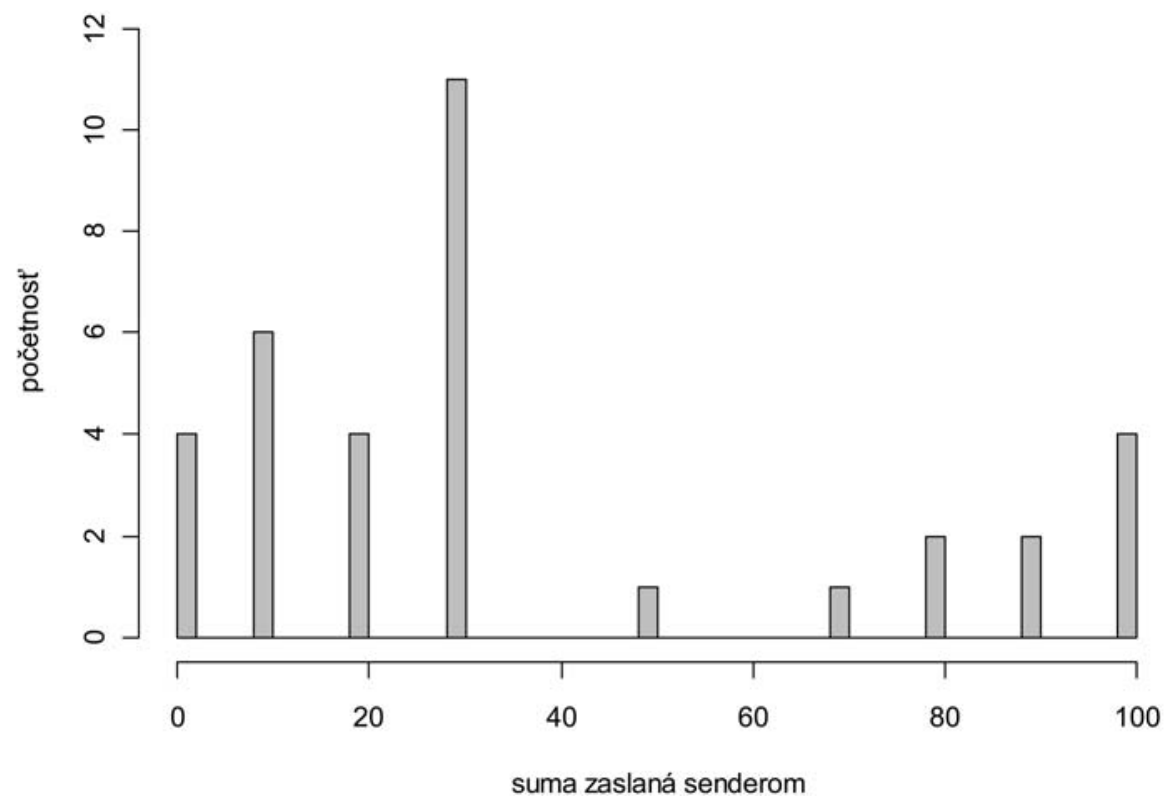

Obrázok 2 znázorňuje histogram súm zaslaných v asymetrickej verzii experimentu. Z 33 senderov ani jeden neposlal $a=0$.

Na základe vizualizácie výsledkov možno povedat', že neohraničená racionalita senderov sa nepotvrdila, a teda subjekty dôverujú senderom. Navyše, v asymetrickej verzii hry si hráči posielajú väššie odnosy súm, čo možno interpretovat' ako fakt, že asymetrická informácia nemá negatívny vplyv na správanie sa senderov. 
Obrázok 2: Histogram súm zaslaných sendermi v asymetrickej verzii hry

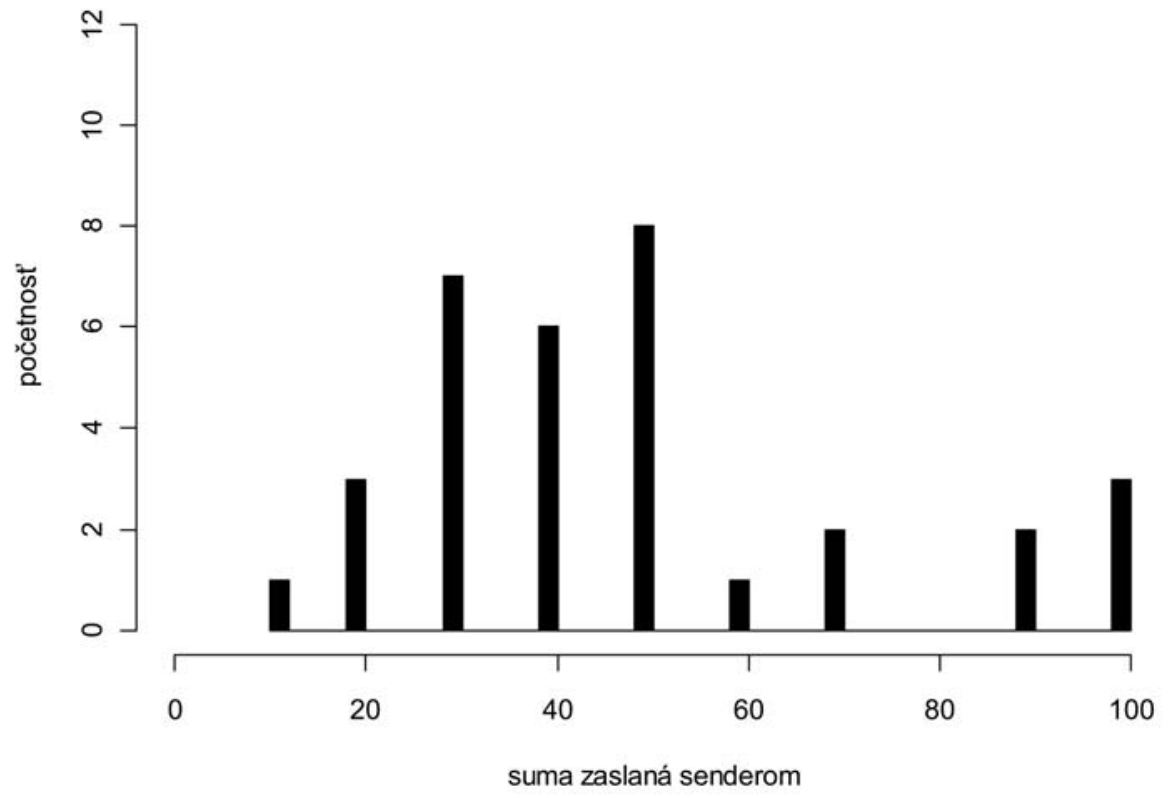

Obrázok 3 znázorňuje histogram súm zaslaných spät’ receivermi v symetrickej verzii hry.

Obrázok 3: Histogram súm zaslaných spät’ receivermi v symetrickej verzii hry

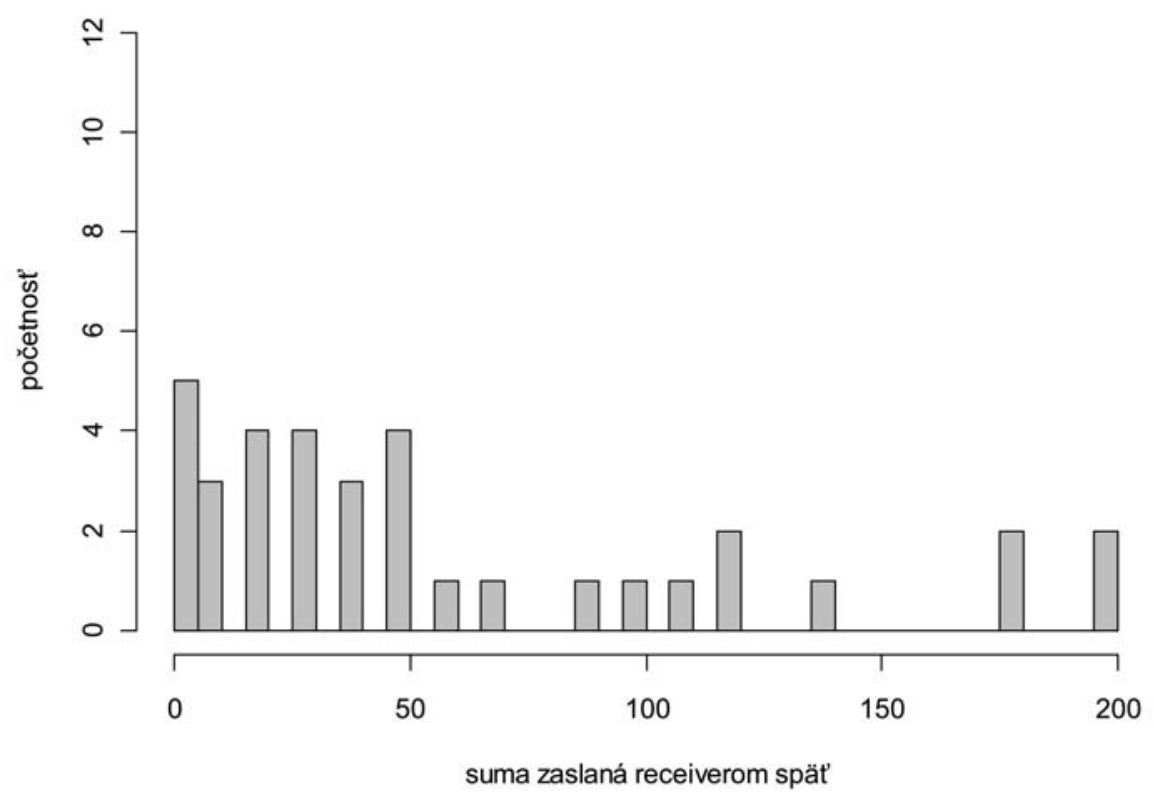


Obrázok 4 znázorn̆uje histogram súm zaslaných receivermi spät’ senderom v asymetrickej verzii hry.

Obrázok 4: Histogram súm zaslaných spät’ receivermi v asymetrickej verzii hry

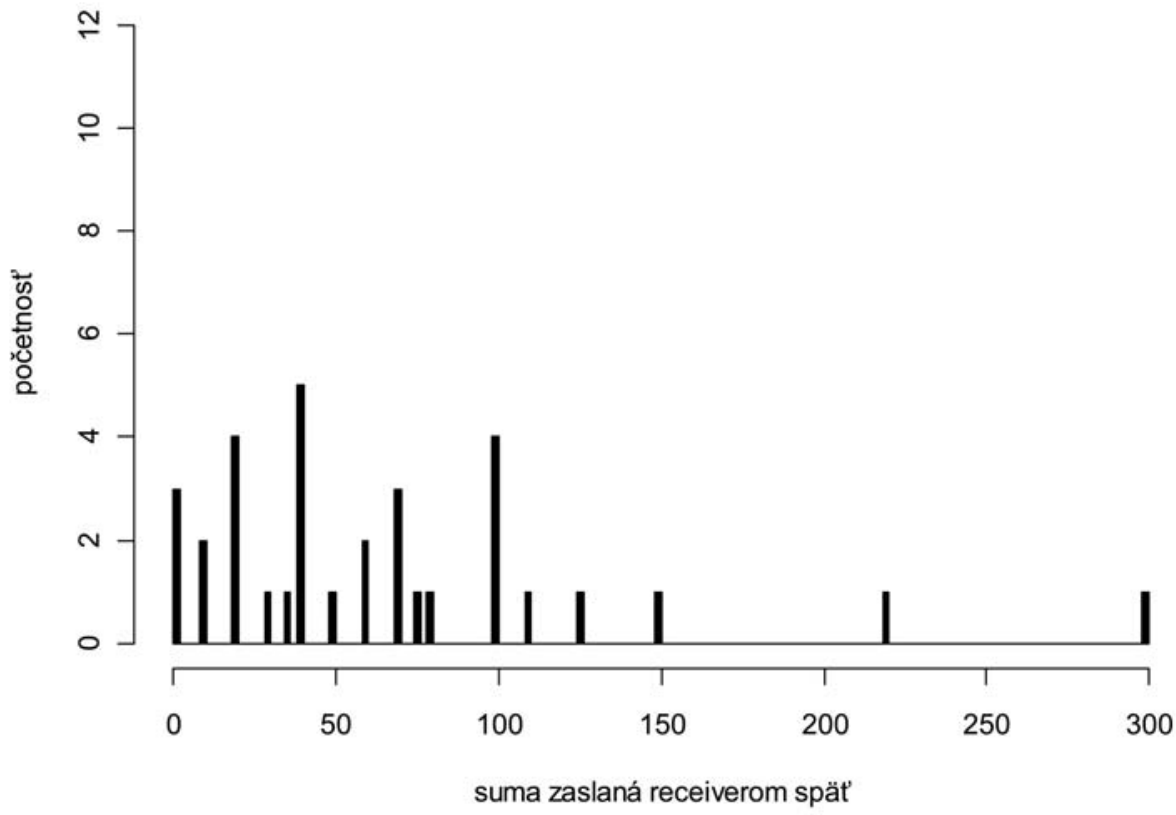

Na testovanie Hypotézy 1: Suma $a=0 \&$ suma $b=0 .(b(a)=0$ pre všetky $a[0, \omega]$ bol použitý binomický test, ktorého hypotézy znejú nasledovne:

$\mathrm{H}_{0}$ : Senderi a receiveri zasielajú vo väčšine prípadov sumy vyššie ako nula.

$\mathrm{H}_{1}$ : Senderi a receiveri nezasielajú vo väčšine prípadov sumy vyššie ako nula.

Tabul'ka 2 sumarizuje výsledky binomického testu pre sumy zasielané medzi hráčmi v symetrickej a asymetrickej verzii experimentu.

Tabul'ka 2: Binomický test súborov

\begin{tabular}{|l|l|l|}
\hline & Sumy odoslané sendermi & Sumy vrátené receivermi \\
\hline Symetrická verzia hry & $\mathrm{p}$-value $=1$ & $\mathrm{p}$-value $=1$ \\
\hline Asymetrická verzia hry & $\mathrm{p}$-value $=1$ & $\mathrm{p}$-value $=1$ \\
\hline
\end{tabular}

Na základe získaných p-hodnôt nezamietame $\mathrm{H}_{0}$ a teda senderi a receiveri zasielajú vo väčšine prípadov sumy vyššie ako nula, a to v oboch variantoch hry.

Na základe výsledkov induktívnej štatistiky zamietame Hypotézu 1: Suma $a=0$ \& suma $b=0 .(b(a)=0$ pre všetky $a[0, \omega]$, čo znamená, že hypotéza o neohraničenej racionalite ekonomických agentov bola zamietnutá. 
Z vizualizácie získaných údajov je zrejmé, že v symetrickej verzii hry z 35 iba 5 receiverov poslalo spät' senderom $b=0$, a v asymetrickej verzii hry zaslali senderom spät' $b=0$ iba 3 z pomedzi 33 receiverov. Možno povedat', že ani v prípade receiverov nebola potvrdená neohraničená racionalita a egoizmus ekonomických agentov, a teda Hypotézu 1: Suma a =0 $\&$ suma $b=0 .(b(a)=0$ pre všetky $a[0, \omega]$ zamietame.

Záverom možno povedat', že zavedenie asymetrickej informácie do investičnej hry nemá vplyv na správanie sa ekonomických agentov.

Hypotéza 2: $\operatorname{Ak}_{x}(b) \geq a$, potom $a>0 ; \& a k\left(a-E_{y}(a)>0\right)$, potom $b \geq a$.

Hypotéza 2 poukazuje na fakt, že medzi subjektmi dochádza ku kooperácii založenej na dôvere, reciprocite a averzii k nespravodlivosti. Jej prvá čast', $E_{X}(b) \geq a$, potom $a>0$, hovorí o tom, že ak sender pošle receiverovi sumu väčšiu ako nula, očakáva od neho aspoň takú istú sumu. Druhá čast' hypotézy, $a k\left(a-E_{Y}(a)>0\right.$, potom $b \geq a$, hovorí o tom, že ak suma, ktorú očakáva receiver je nižšia ako suma, ktorú mu poslal sender, receiver pošle spät’ sumu aspoň takú vysokú, ako mu poslal sender, $b \geq a$. Obrázok 5 znázorňuje, v kol'kých prípadoch z 35 došlo k potvrdeniu Hypotézy 2: $A k E_{X}(b) \geq a$, potom $a>0 ; \& a k\left(a-E_{Y}(a)>0\right.$, potom $b \geq a$ v prvom kole symetrického variantu hry.

Obrázok 5: Očakávania a zaslané sumy v prvom kole symetrickej verzie hry

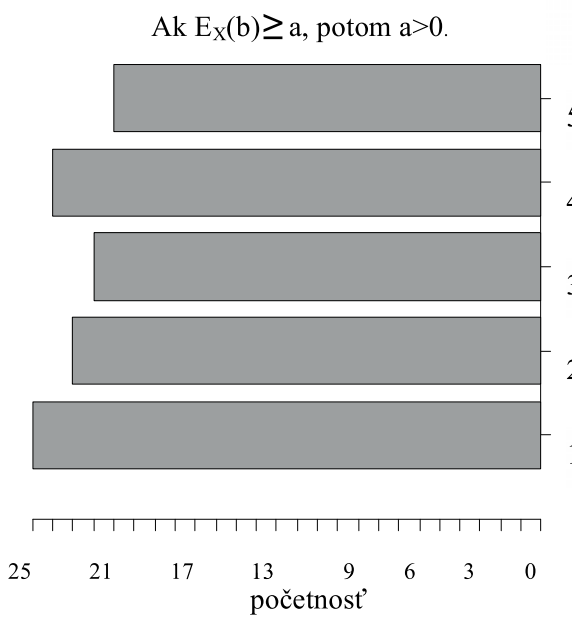
$\operatorname{Ak}\left[\mathrm{a}-\mathrm{E}_{\mathrm{Y}}(\mathrm{a})\right]>0$, potom $\mathrm{b}>\mathrm{a}$
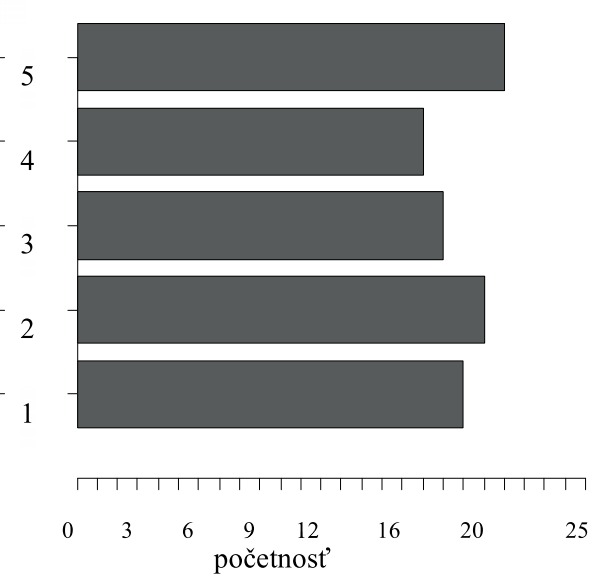

Obrázok 6 znázorňuje, v kol'kých prípadoch z 33 došlo k potvrdeniu Hypotézy 2: $A k E_{X}(b) \geq a$, potom $a>0 ; \& a k\left(a-E_{Y}(a>0)\right.$, potom $b \geq a \mathrm{v}$ prvom kole asymetrického variantu hry. 
Obrázok 6: Očakávania a zaslané sumy v prvom kole asymetrickej verzie hry
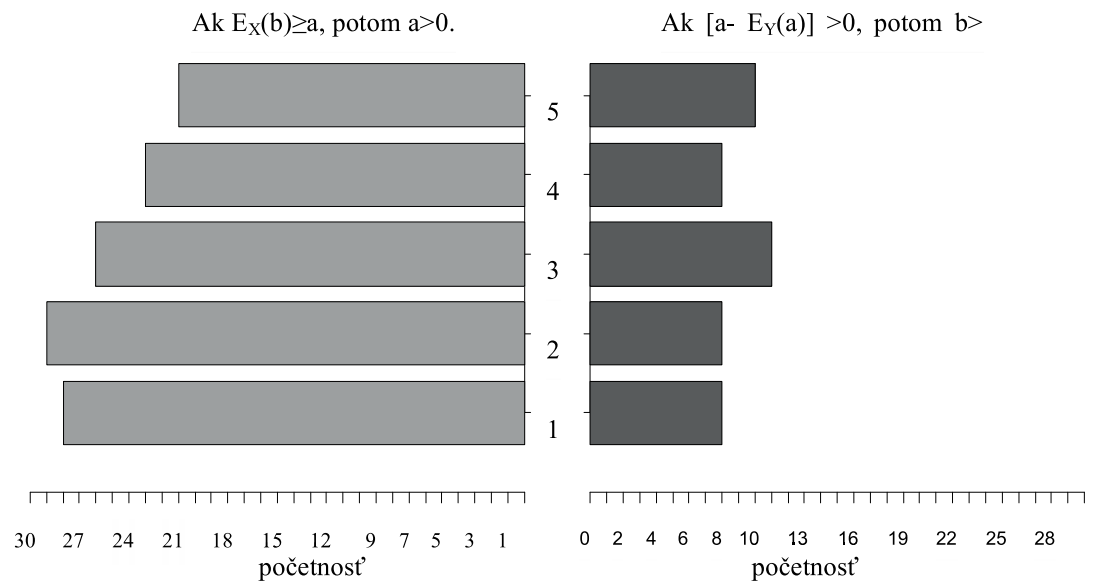

Uvedené možno interpretovat' ako dôveru senderov, ktorá je podložená predpokladom pozitívnej reciprocity receiverov. Pri asymetrickej verzii ale receiveri z časti využívajú svoju informačnú výhodu a $a k\left[a-E_{Y}(a)\right]>0$, potom $b>a$ je naplnená v prípadoch, ktorých celková početnost' je o $50 \%$ nižšia, ako u symetrickej verzie hry.

Hypotéza 3: Sumy a \& b, ktoré si navzájom účastníci X a Y posielajú, sú pozitívne korelované.

Hypotéza 3 vyšetruje, či je reciprocita indukovaná v investičnej hre prostredníctvom dôvery. To znamená, že receiveri odmeňujú akcie nesúce náznaky dôvery a trestajú akcie, ktoré v sebe nesú prvky egoizmu a nedôvery.

Pearsonové korelačné koeficienty pre symetrickú verziu hry a pre asymetrickú verziu hry v priebehu piatich kôl sú v Tabul'ke 3 .

Tabul'ka 3: Korelačné koeficienty medzi sumami $\boldsymbol{a} \boldsymbol{\&} \boldsymbol{b}$

\begin{tabular}{|l|c|c|c|c|c|}
\hline Kolo & 1. & 2. & 3. & 4. & 5. \\
\hline Symetrická verzia hry & 0,84523 & 0,663072 & 0,574749 & 0,712917 & 0,725263 \\
\hline Asymetrická verzia hry & 0,312303 & 0,54148 & 0,780089 & 0,823919 & 0,788683 \\
\hline
\end{tabular}

Na základe hodnôt korelačných koeficientov v jednotlivých kolách hry možno povedat’, že sumy $a$ a $b$ sú pozitívne korelované. Slabým miestom korelačnej analýzy je prvé kolo asymetrickej verzie hry, kde je Pearsonov korelačný koeficient rovný 0,31 . V sociálnych vedách je možné interpretovat' hodnotu Pearsonovho koeficientu medzi 0,3-0,5 za strednú závislost'. Pearsonov korelačný koeficient je v prípade prvého kola asymetrickej verzie hry rovný 0,312303 . Záverom je možné povedat', že hodnoty korelačných koeficientov sú v prvom kole asymetrickej verzie hry afektované extrémnymi hodnotami. Obrázky 7 a 8 zobrazujú priebeh korelácie v prvom kole experimentu. 
Matúš Kubák, Vladimír Gazda, Zuzana Lejková, Jozef Nemec: Kvantitatívny pohl'ad na vplyv...

Obrázok 7: Scatter plot zasielaných súm v symetrickej verzii hry

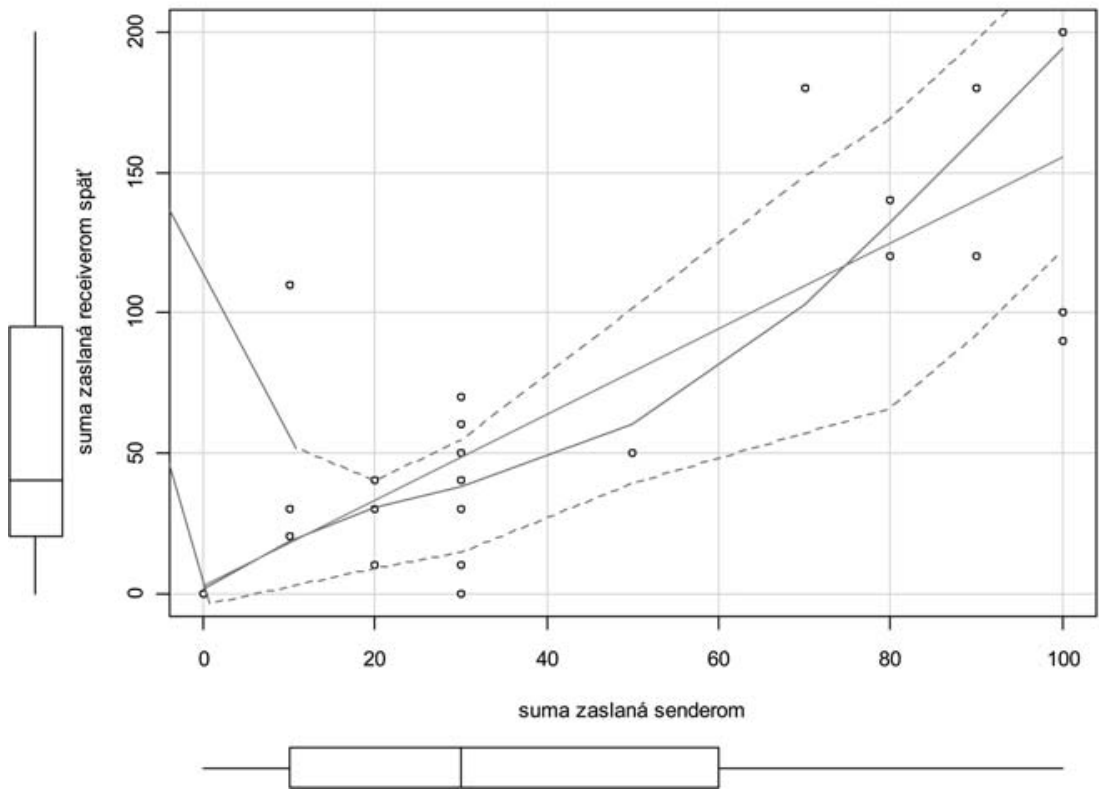

Na obrázku 8 je vidiet' extrémne hodnoty, ktoré skreslili koeficient korelácie v prvom kole experimentu asymetrickej verzie hry.

Obrázok 8: Scatter plot zasielaných súm v asymetrickej verzii hry

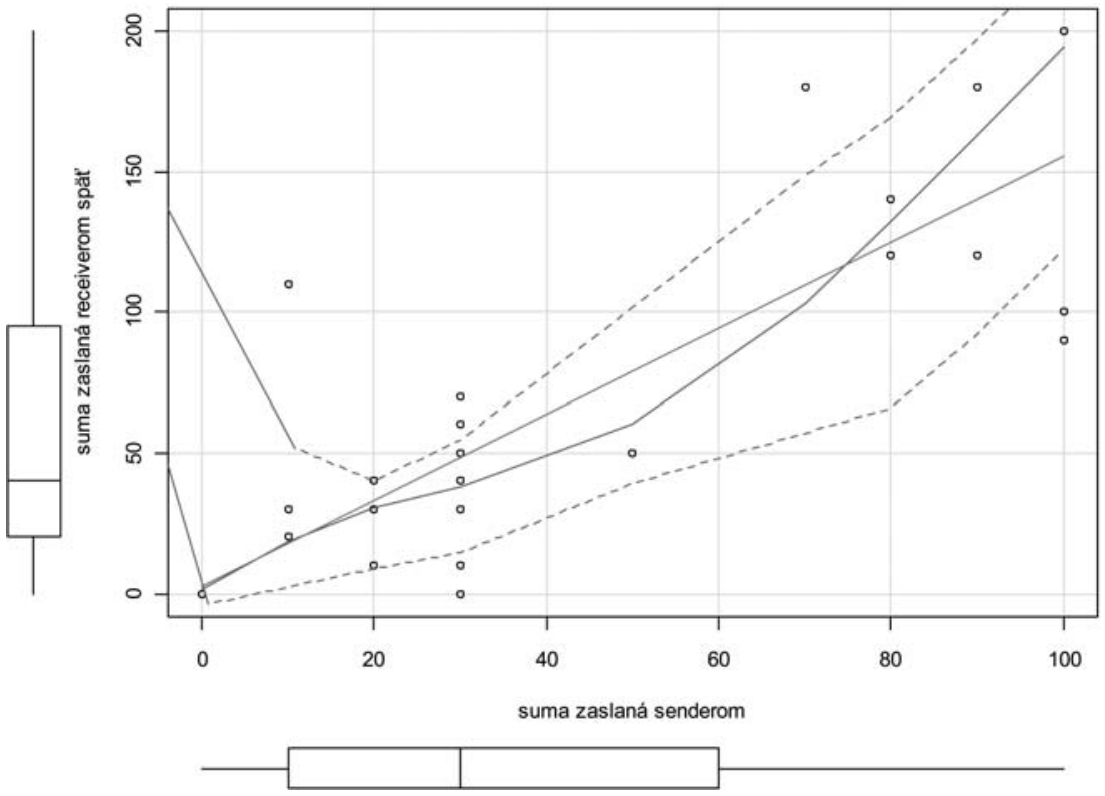


Obrázky 9 a 10 vizualizujú sumy zasielané v rámci párov v prvom kole experimentu. Z Obrázku 9 je zrejmé, že v symetrickej verzii iba pät' receiverov poslalo senderom spät' $b<a$. $\mathrm{V}$ asymetrickej verzii experimentu poslalo v prvom kole $b<a 12$ subjektov.

Obrázok 9: Sumy zasielané v rámci dvojíc v asymetrickej verzii experimentu v prvom kole

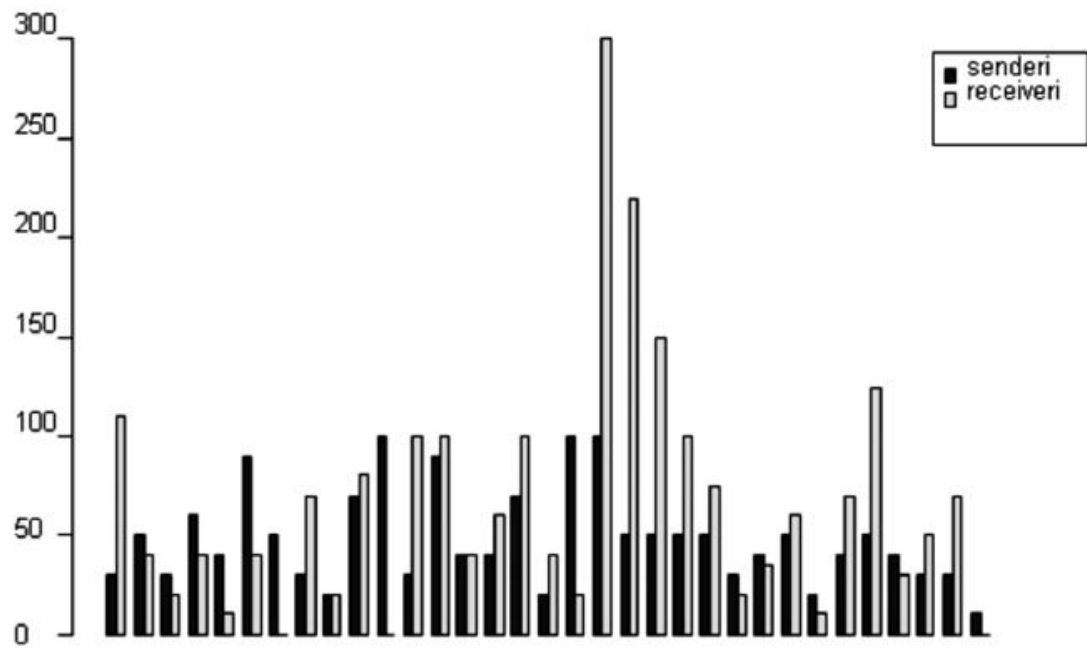

$\begin{array}{lllllllllllllllll}1 & 3 & 5 & 7 & 9 & 11 & 13 & 15 & 17 & 19 & 21 & 23 & 25 & 27 & 29 & 31 & 33\end{array}$

Obrázok 10: Sumy zasielané v rámci dvojíc v symetrickej verzii experimentu v prvom kole

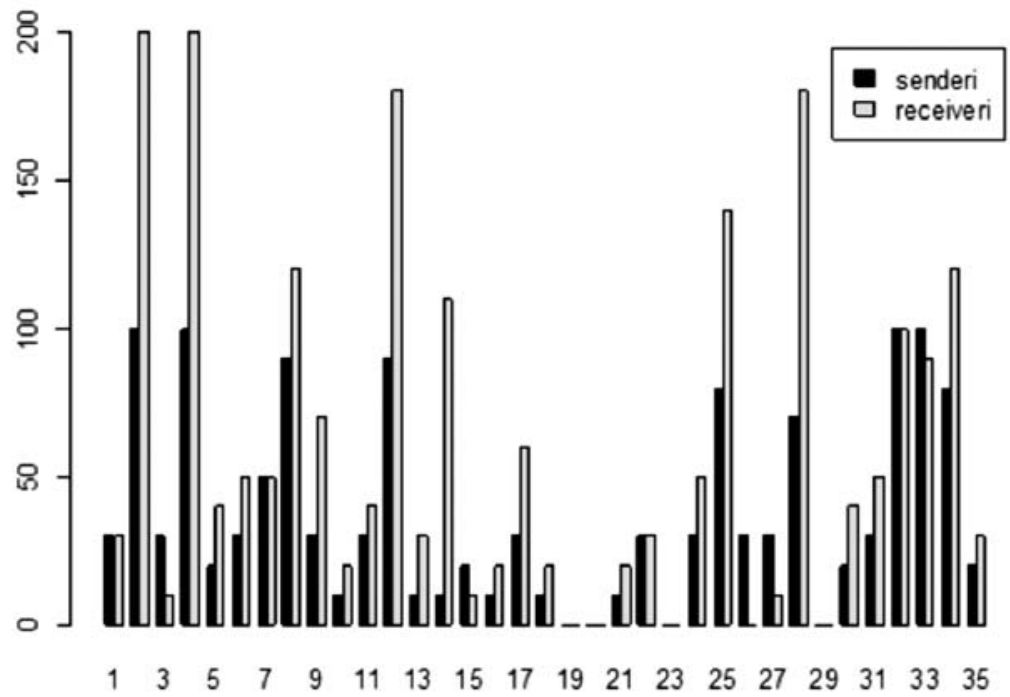


Záverom korelačnej analýzy je nezamietnutie Hypotézy 3: Sumy $a \&$ b ktoré si navzájom účastníci X a Y posielajú, sú pozitívne korelované. To znamená, že zavedenie asymetrickej informácie nemá vplyv na kooperáciu ekonomických agentov v prostredí investičnej hry.

Hypotéza 4: Suma b, ktorú posiela účastník Y späf účastníkovi $X$, je rovnaká pre $m=2 \& m=4$.

Táto hypotéza je zameraná na oportunistické správanie sa receiverov. Ciel’om hypotézy je skúmat' vplyv asymetrickej informácie na konanie hráčov (receiverov) v investičnej hre. Testovanie hypotézy bolo obmedzené na prvé kolo experimentu, nakol'ko iba takto sa dalo predíst' vplyvu reputácie, učenia sa a d’alších faktorov. Ak hráči inklinujú k oportunizmu, tak potom platí $\mathrm{b}_{\mathrm{m}=2}=\mathrm{b}_{\mathrm{m}=4}$. Ak hráči, receiveri neinklinujú $\mathrm{k}$ oportunizmu a sú féroví, tak potom $\mathrm{b}_{\mathrm{m}=2}<\mathrm{b}_{\mathrm{m}=4}$, nakol'ko nezneužívajú svoju informačnú výhodu, spočívajúcu v poznaní hodnoty multiplikátora. Deskriptívna štatistika súm zasielaných a asymetrickej verzii pre $\mathrm{m}=2$ a pre $\mathrm{m}=4$ je $\mathrm{v}$ Tabul'ke 4 .

Tabul'ka 4: Deskriptívna štatistika súm zaslaných spät’ pre $\mathrm{m}=2$ a $\mathrm{m}=4$

\begin{tabular}{|l|c|c|c|}
\hline & priemer & medián & smerodajná odchýlka \\
\hline $\mathbf{m}=\mathbf{2}$ & 56,99 & 48,22 & 48,22 \\
\hline $\mathbf{m}=\mathbf{4}$ & 86,36 & 77,41 & 77,41 \\
\hline
\end{tabular}

Deskriptívna štatistika naznačuje, že sumy pre dve úrovne multiplikátora sa líšia. Grafické znázornenie rozdielov medzi sumami zasielanými pri $\mathrm{m}=2$ a pri $\mathrm{m}=4$ sú znázornené na Obrázku 11.

Obrázok 11: Boxplot súm zaslaných spät' pre $\mathrm{m}=2 \mathrm{a} \mathrm{m}=4 \mathrm{v}$ prvom kole experimentu

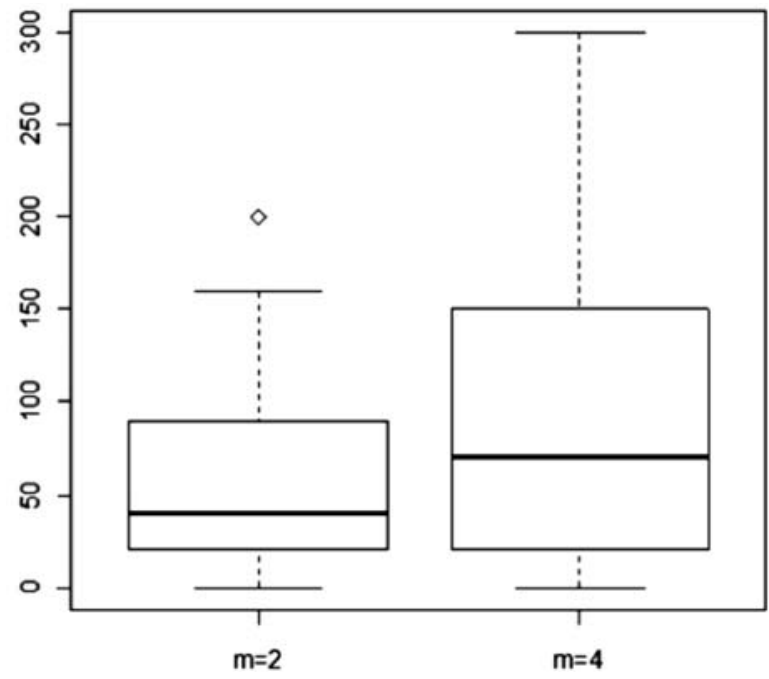


Na základe vizualizácie výsledkov a deskriptívnej štatistiky možno povedat', že sumy zasielané pre $\mathrm{m}=2$ a $\mathrm{m}=4$ nie sú rovnaké a receiveri nemajú tendenciu správat' sa oportunisticky. Na podloženie záveru bude využitá štatistická indukcia. Na testovanie rozdielov medzi sumami $b$ zasielanými spät' receivermi v asymetrickej verzii experimentu bude použitý Wilcoxon rank-sum test:

$\mathrm{H}_{0}$ : Rozdiel medzi sumami zasielanými receivermi spät' pre $\mathrm{m}=2 \mathrm{a} \mathrm{m}=4$ nie je štatisticky významný.

$\mathrm{H}_{1}$ : Rozdiel medzi sumami zasielanými receivermi spät' pre $\mathrm{m}=2$ a $\mathrm{m}=4$ je štatisticky významný.

P hodnota $(\mathrm{W}=2795.5, \mathrm{p}$-value $=0.06433)$ je väčšia ako hladina významnosti $\alpha=0,05$, teda nezamietame hypotézu $\mathrm{H}_{0}$ o rovnosti súm zasielaných spät’ pre $\mathrm{m}=2 \mathrm{a} \mathrm{m}=4$.

Závery deskriptívnej štatistiky naznačujú, že sumy zasielané receivermi spät’ pre $\mathrm{m}=2$ a $\mathrm{m}=4$ sú rozdielne, Wilcoxon rank-sum test poukazuje na fakt, že sumy $\mathrm{b}_{\mathrm{m}=2}=\mathrm{b}_{\mathrm{m}=4}$, teda $\mathrm{u}$ receiverov dochádza $\mathrm{k}$ oportunistickému správaniu sa a využívaniu informačnej výhody. Záver induktívnej štatistiky ale nie je štatisticky dostatočne podložený, nakol'ko je vzorka príliś malá, rozptyl príliś vel'ký a p-hodnota príliš nízka. Záverom sa prikláňame k názoru, že receiveri sa nesprávajú oportunisticky a nevyužívajú naplno svoju informačnú výhodu.

Hypotéza 5: Pre sumy, ktoré posiela hráč X v prvých štyroch kolách experimentu, platí $a_{1}<a_{2}<a_{3}<a_{4} \&$ pre sumy, ktoré posiela hráč $Y \vee$ prvých štyroch kolách späf hráčovi $\mathrm{X}$, platí $\mathrm{b}_{1}<\mathrm{b}_{2}<\mathrm{b}_{3}<\mathrm{b}_{4}$.

Táto hypotéza sa snaží dokázat', že s opakovaním experimentu dochádza medzi hráčmi $\mathrm{v}$ dvojici $\mathrm{k}$ vytvoreniu reputácie a $\mathrm{k}$ nárastu dôvery, resp. reciprocity a tým $\mathrm{k}$ rastu ziskov subjektov. Posledné kolo je z analýzy vynechané, nakol'ko subjektom bolo povedané, že ide o posledné kolo, a teda výsledky by mohli byt' ovplyvnené step out efektom.

Obrázok 12 zobrazuje priemerné sumy zaslané v piatich kolách experimentu symetrickej verzie hry. Obrázok 13 vizualizuje priemerné sumy zaslané v piatich kolách experimentu asymetrickej verzie hry.

Z vizualizácie údajov súm zaslaných v jednotlivých kolách nie je možné jednoznačne vyrieknut' záver ohl'adom predpokladu, že $\mathrm{a}_{1}<\mathrm{a}_{2}<\mathrm{a}_{3}<\mathrm{a}_{4} \mathrm{a}_{\mathrm{b}_{1}}<\mathrm{b}_{2}<\mathrm{b}_{3}<\mathrm{b}_{4}$ v asymetrickej a symetrickej verzii hry. Štatisticky bude táto hypotéza testovaná Wilcoxon Signed-Rank testom. Výsledky testu sú uvedené v Tabul'ke 5 a v Tabul'ke 6. 
Obrázok 12: Priemerné sumy zaslané počas experimentu v symetrickej verzii hry

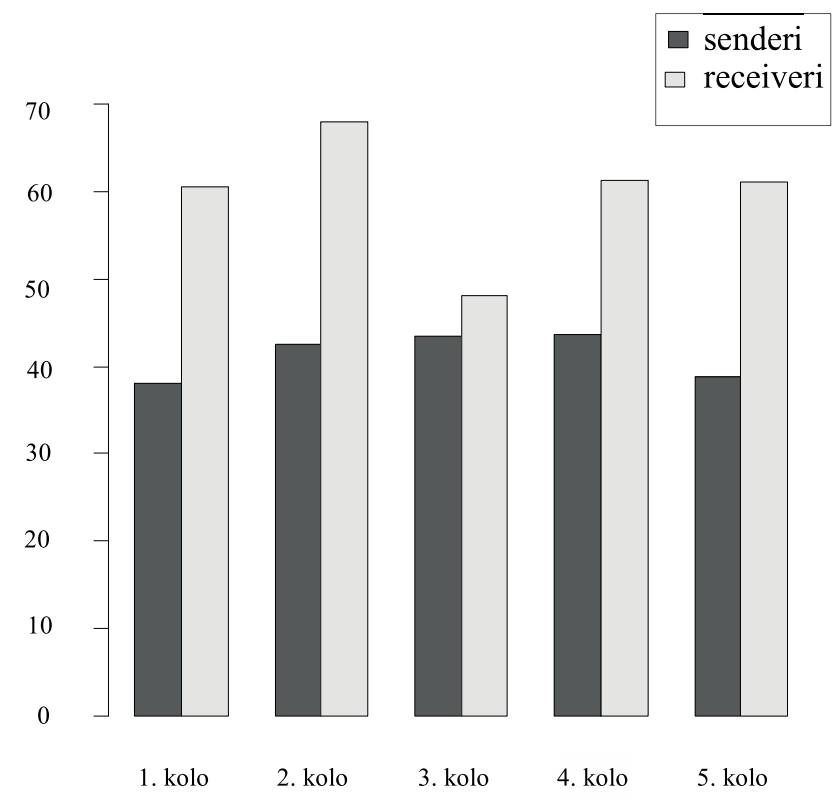

Obrázok 13: Priemerné sumy zaslané počas experimentu v asymetrickej verzii hry
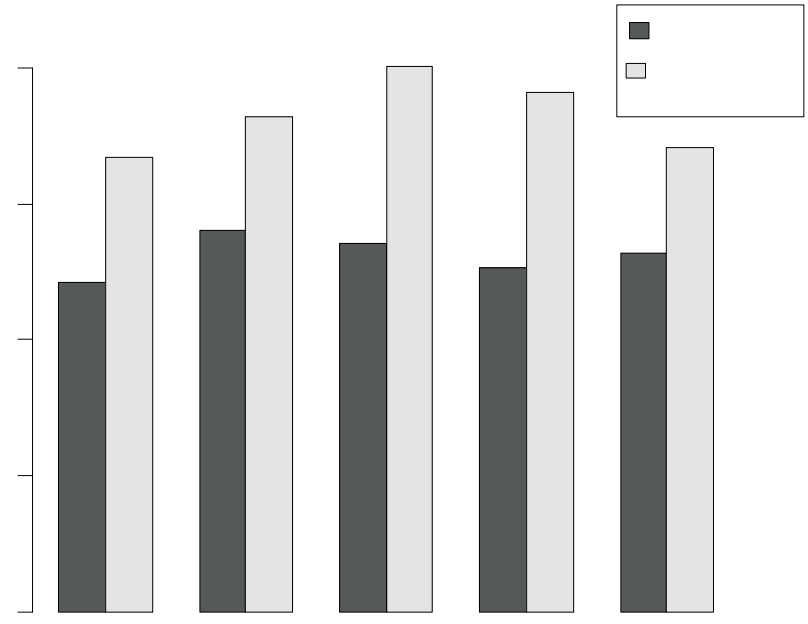

Wilcoxon Signed-Rank Test:

$\mathrm{H}_{0}$ : Údaje pochádzajú z identických populácií.

$\mathrm{H}_{1}$ : Údaje nepochádzajú z identických populácií. 
Tabul'ka 5: Wilcoxon Signed-Rank Test pre sumy zaslané sendermi

\begin{tabular}{|l|c|c|}
\hline & Symetrická verzia hry & Asymetrická verzia hry \\
\hline$a_{1}=a_{2}$ & $p$-value $=0.2248$ & $p$-value $=0.07522$ \\
\hline$a_{2}=a_{3}$ & $p$-value $=0.3892$ & $p$-value $=0.5906$ \\
\hline$a_{3}=a_{4}$ & $p$-value $=0.8393$ & $p$-value $=0.7092$ \\
\hline
\end{tabular}

Tabul'ka 6: Wilcoxon Signed-Rank Test pre sumy zaslané receivermi

\begin{tabular}{|l|c|c|}
\hline & Symetrická verzia hry & Asymetrická verzia hry \\
\hline $\mathbf{b}_{1}=\mathbf{b}_{2}$ & $\mathrm{p}$-value $=0.3317$ & $\mathrm{p}$-value $=0.704$ \\
\hline $\mathbf{b}_{2}=\mathbf{b}_{3}$ & $\mathrm{p}$-value $=0.3787$ & $\mathrm{p}$-value $=0.6205$ \\
\hline $\mathbf{b}_{3}=\mathbf{b}_{4}$ & $\mathrm{p}$-value $=0.1901$ & $\mathrm{p}$-value $=0.5111$ \\
\hline
\end{tabular}

Z tabuliek 5 a 6 je zrejmé, že p hodnoty testov sú väčšie ako hladina významnosti $\alpha=0,05$. Hypotézu $\mathrm{H}_{0}$ tvrdiacu, že údaje pochádzajú z identických populácií, nezamietame, a teda rozdiely v sumách zasielaných v jednotlivých kolách nie sú štatisticky významné. Efekt budovania reputácie nie je potvrdený.

Hypotéza 6: Suma $a_{5}$ poslaná hráčom $X$ hráčovi Y v piatom (poslednom) kole je menšia ako suma $a_{4}$ poslaná hráčom $X$ hráčovi $Y$ vo štvrtom kole. Suma $b_{5}$ poslaná hráčom Y hráčovi X späł v piatom (poslednom) kole je rovná nule.

Hypotéza 6 je zameraná na sledovanie step out effectu, kedy hráč X prestáva verit’ hráčovi $\mathrm{Y}$, pretože je prítomné riziko oportunistického správania sa, teda zbehnutia z kooperácie, nakol'ko ide o poslednú interakciu hráčov počas hry.

Priemer zaslaných súm sendermi vo štvrtom kole je v symetrickej verzii 44 EPJ a v asymetrickej verzii 51 EPJ. Priemer zaslaných súm sendermi v piatom kole experimentu je v symetrickej verzii 39 EPJ a v asymetrickej verzii 53 EPJ. Na testovanie Hypotézy 6 bude využitý Wilcoxon Signed-Rank test. Pri prvej časti Hypotézy 6 týkajúcej sa rozdielu medzi sumami $\mathrm{a}_{4} \& \mathrm{a}_{5}$, ktoré zasielajú senderi vo štvrtom a piatom kole, znejú hypotézy nasledovne:

$\mathrm{H}_{0}$ : Údaje zo štvrtého a piateho kola experimentu $\mathrm{a}_{4} \& \mathrm{a}_{5}$, ktoré zasielajú senderi, pochádzajú z identických populácií.

$\mathrm{H}_{1}$ : Údaje zo štvrtého a piateho kola experimentu $\mathrm{a}_{4} \& \mathrm{a}_{5}$, ktoré zasielajú senderi, nepochádzajú z identických populácií.

Pri druhej časti Hypotézy 6 týkajúcej sa súm $b_{5}$, ktoré zasielajú receiveri v piatom kole spät', znejú hypotézy znamienkového testu nasledovne:

$\mathrm{H}_{0}$ : Medián zaslaných súm v piatom kole je rovný nule.

$\mathrm{H}_{1}$ : Medián zaslaných súm v piatom kole je väčší ako nula. 
Výsledky testov sú v Tabul'ke 7.

Tabul'ka 7: Wilcoxon Signed-Rank Test pre sumy zasielané sendermi a znamienkový test pre sumy zasielané receivermi v piatom kole

\begin{tabular}{|l|c|c|}
\hline & Sumy $\mathrm{a}_{4}=\mathrm{a}_{5}$ & Sumy $\mathrm{b}_{5}=0$ \\
\hline Symetrická verzia hry & $\mathrm{p}$-value $=0.50926$ & $\mathrm{p}$-value $=1.192 \mathrm{e}-07$ \\
\hline Asymetrická verzia hry & $\mathrm{p}$-value $=0.42952$ & $\mathrm{p}$-value $=2.98 \mathrm{e}-08$ \\
\hline
\end{tabular}

Na základe výsledkov Wilcoxon Signed-Rank testu a znamienkového testu uvedených v Tabul'ke 7 možno povedat', že sa step out effect neprejavil a že hráči nie sú náchylní na zbehnutie z kooperácie. V prípade súm zasielaných sendermi nie je štatisticky významný rozdiel medzi $\mathrm{a}_{4} \mathrm{a}_{5}$. $\mathrm{V}$ prípade súm zasielaných receivermi je medián štatisticky významne vyšší od nuly.

Hypotéza 7: Sumy a \& b, ktoré si hráči posielajú v jednotlivých kolách, sú rovnaké pre symetrickú verziu hry aj asymetrickú verziu experimentu.

Hypotéza 7 sleduje škodlivost' asymetrickej informácie na dôveru a dôveryhodnost' ekonomických agentov. Ak je asymetrická informácia škodlivá, rozdiel medzi sumami zasielanými v symetrickej verzii experimentu a asymetrickej verzii experimentu bude štatisticky významný. Na testovanie Hypotézy 7 bude využitý Mann-Whitney U Test.

Mann-Whitney U Test:

$\mathrm{H}_{0}$ : Sumy zasielané $\mathrm{v}$ piatich kolách experimentu v symetrickej a asymetrickej verzii pochádzajú z rovnakej populácie.

$\mathrm{H}_{1}$ : Sumy zasielané v piatich kolách experimentu v symetrickej a asymetrickej verzii nie sú z rovnakej populácie.

Z Tabul'ky 8 je zrejmé, že sumy $a \& b$ sa pre symetrickú a asymetrickú verziu experimentu signifikantne nelíšia (až na prípad prvého kola pri senderoch a tretieho kola pri receiveroch). Záverom možno povedat', že asymetrická informácia nemá vplyv na sumy, ktoré posielajú senderi a receiveri.

Tabul'ka 8: Mann-Whitney U Test pre sumy a zaslané sendermi a pre sumy b zaslané receivermi

\begin{tabular}{|l|c|c|}
\hline & Sumy a zaslané sendermi & Sumy b zaslané receivermi \\
\hline 1. kolo & $\mathrm{p}$-value $=0.01618$ & $\mathrm{p}$-value $=0.4905$ \\
\hline 2. kolo & $\mathrm{p}$-value $=0.08853$ & $\mathrm{p}$-value $=0.2339$ \\
\hline 3. kolo & $\mathrm{p}$-value $=0.1416$ & $\mathrm{p}$-value $=0.01773$ \\
\hline 4. kolo & $\mathrm{p}$-value $=0.504$ & $\mathrm{p}$-value $=0.5476$ \\
\hline 5. kolo & $\mathrm{p}$-value $=0.1144$ & $\mathrm{p}$-value $=0.5135$ \\
\hline
\end{tabular}




\section{Záver}

Záverom možno konštatovat', že asymetrická informácia nemá rozhodujúci vplyv na správanie sa ekonomických agentov, l’udí, v prostredí investičnej hry. Na základe analýzy získaných údajov sa nepotvrdila neohraničená racionalita senderov a receiverov. Sumy $a \& b$, ktoré si účastníci experimentu posielajú, sú pozitívne korelované v oboch variantoch hry, čo svedčí o existencii recipročného správania sa. Receiveri v asymetrickej verzii hry nemajú tendenciu k oportunistickému správaniu sa, čo znamená, že nevyužívajú svoju informačnú výhodu a pre rôzne hodnoty multiplikátora zasielajú spät' rozdielne sumy $b$. Efekt reputácie potvrdený nebol, čo znamená, že sumy, ktoré si hráči zasielali počas experimentu, s pribúdajúcimi kolami štatisticky významne nenarastali. Step out efekt nebol potvrdený a teda hráči nemajú tendenciu zbehávat' z kooperácie. Senderi nie sú averzní voči nespravodlivosti, teda neveria, že im receiveri zašlú spät' sumu, ktorá bude spravodlivým rozdelením výnosu $\mathrm{z}$ investície. Receiveri v symetrickej verzii hry sú averznejší voči nespravodlivosti ako receiveri v asymetrickej verzii hry. Uvedené možno vysvetlit' tým, že receiveri v asymetrickej verzii experimentu z časti využívajú svoju informačnú výhodu týkajúcu sa poznania hodnoty multiplikátora a senderom zasielajú spät' sumy, ktoré nekorešpondujú so spravodlivým rozdelením výnosu z investície. Hráči si počas experimentu posielali sumy príbuzné sumám, ktoré si hráči zasielali v referenčných experimentoch. Aj ked’ pravdou je, že dôvera senderov na Slovensku je najnižšia v porovnaní so všetkými referenčnými experimentmi. Navyše, dôvera v asymetrickej verzii hry je vyššia, ako dôvera v symetrickej verzii hry. Ďalšou zaujímavost'ou predloženého experimentu je rozdiel v dôveryhodnosti receiverov na Slovensku. Receiveri na Slovensku zasielajú senderom spät' v priemere viac experimentálnych peňažných jednotiek ako receiveri z iných krajín.

\section{Literatura}

AHMED, Ali M. a Osvaldo SALAS. 2008. „Trust in India and Sweden.” Cross-Cultural Research 42(4): 420-429.

BEN-NER, Avner a Louis PUTTERMAN. 2009. „Trust, Communication and Contracts: An Experiment." Journal of Economic Behavior \& Organization 70(1-2): 106-121.

BERG, Joyce, John DICKHAUT a Kevin McGABE. 1995. „Trust, Reciprocity and Social History.” Games and Economic Behavior 10(1): 122-142.

CESARINI, David, Christopher T. DAWES, James H. FOWLER, Magnus JOHANNESSON a Paul LICHTENSTEIN. 2008. „Heritability of cooperative behavior in the trust game.” Proceedings of the National Academy of Sciences of the United States of America 10(105): 3721-3726.

CORICELLI, Giorgio, Luis GONZÁLEZ MORALES a Amelie MAHLSTEDT. 2006. „The investment game with asymmetric information." Metroeconomica 57(1): 13-30.

COX, James C. a Cary A. DECK. 2006. „When are Women More Generous than Men?” Economic Inquiry (44)4: 587-598.

COX, James C., Daniel FRIEDMAN a Vjollca SADIRAJ. 2008. „Revealed Altruism.” Econometrica (76)1: 31-69. 
CSUKAS, Csongor, Paulo FRACALANZA, Tamás KOVÁCS a Marc WILLINGER. 2008. „The Determinants of Trusting and Reciprocal Behaviour: Evidence from an Intercultural Experiment." Journal of Economic Development (33)1: 71-95.

ENGELMANN, Dirk a Urs FISCHBACHER. 2009. „Indirect reciprocity and strategic reputation building in an experimental helping game.“ Games and Economic Behavior (67)2: 399-407.

FEHR, Ernst a Klaus M. SCHMIDT. 1999. „A theory of fairness, competition and cooperation.” Quarterly Journal of Economics 114(3): 817-868.

FERSHTAN, Chaim a Uri GNEEZY. 2001. „Discrimination in a segmented society: an experimental approach." Quarterly Journal of Economics 116(1): 351-377.

FUKUYAMA, Francis. 1996. Trust: the social virtues and the creation of prosperity. New York: Free Press.

GREIG, Fiona a Iris BOHNET. 2008. „Is There Reciprocity in a Reciprocal Exchange Economy? Evidence from a Slum in Nairobi." Economic Inquiry (46)1: 77-83.

GRÓF, Marek, Lucia LECHOVÁ, Vladimír GAZDA a Matúš KUBÁK. 2012. „An Experiment on the Level of Trust in an Expanded Investment Game.” Journal of Applied Sciences (12)12: 1308-1312.

HOLM, Hakan J. a Anders DANIELSON. 2005. „Tropic Trust Versus Nordic Trust: Experimental Evidence From Tanzania And Sweden.” Economic Journal 115(503): 505-532.

JOHNSON, Noel D. a Alexandra A. MISLIN. 2011. „Trust games: A meta-analysis.“ Journal of Economic Psychology 32(5): 865-889.

KOSFELD, Michael, Markus HEINRICHS, Paul J. ZAK, Urs FISCHBACHER a Ernst FEHR. 2005. „Oxytocin Increases Trust in Humans.” Nature 435: 673-676.

STANTON, Angela A. 2009. Neural Substrates of Decision-Making in Economic Games: Hormones in Decision-Making. Saarbrücken: VDM Verlag.

TAKAHASI, Chisato, Toshio YAMAGISHI, Shigehito TANIDA, Toko KIYONARI a Satoshi KANAZAWA. 2006. „Attractiveness and Cooperation in Social Exchange.” Evolutionary Psychology 4: 315-329.

\section{Autori}

Matúš Kubák je odborným asistentom na Ekonomickej fakulte Technickej univerzity v Košiciach. Odborne sa profiluje ako kvantitatívny ekonóm so zameraním na ekonometriu a experimentálnu ekonómiu v kontexte korupcie.

Kontakt: matus.kubak@tuke.sk

Vladimír Gazda je profesorom na Ekonomickej fakulte Technickej univerzity v Košiciach. Jeho odborný profil je zameraný na aplikáciu ekonometrie, matematických modelov, experimentálnej ekonómie, kvantitatívnej mikroekonómie a agent based modelovania do vedecko-výskumného a pedagogického procesu.

Kontakt: vladimir.gazda@tuke.sk

Zuzana Lejková do júla 2010 pôsobila ako asistentka a neskôr ako odborná asistentka na Katedre ekonómie Podnikovohospodárskej faktulty Ekonomickej univerzity v Bratislave so sídlom v Košiciach, kde sa venovala problematike konkurencieschopnosti podnikov s dôrazom na malé a stredné podniky.

Kontakt: riaditel@gymbosak.sk 
Jozef Nemec od roku 2011 pôsobí ako odborný asistent na Katedre ekonómie a ekonomiky na Fakulte manažmentu Prešovskej univerzity v Prešove. Vo svojej pedagogickej a výskumnej práci sa venuje ekonómii, podnikovej ekonomike a tiež logistike.

Kontakt: jozef.nemec@unipo.sk

\section{Prílohy}

\section{Inštrukcie pre HRÁČA X - SENDER/FIRST MOVER}

Vážený účastník experimentu, vítame Vás na experimente.

Počas trvania experimentu Vás prosíme nerozprávat' sa alebo inak nekomunikovat's ostatnými účastníkmi experimentu.

Ako účastníci experimentu ste boli náhodne rozdelení do dvojíc. Každá dvojica je tvorená hráčom X a hráčom Y.

1) Obaja hráči majú na začiatku 100 EPJ (experimentálna peňažná jednotka).

2) Úlohou hráča X, ktorý je na t’ahu ako prvý, je urobit' rozhodnutie, kol'ko peňazí zo 100 $E P J$ (experimentálna peňažná jednotka), chce poslat’ hráčovi Y.

3) Tomu sa získaná suma zhodnotí trojnásobne.

4) Po zhodnotení je na t'ahu hráč Y. Jeho úlohou je rozhodnút' sa, akú výšku peňazí vyplatí spät' hráčovi X (môže zvolit' aj nulu).

\section{Celú situáciu si pozrite na schéme pod textom.}

Obálku, ktorú ste si vytiahli, Vás určila stat' sa hráčom $\boldsymbol{X}$. Ste teda na t’ahu prvý.

K dispozícii máte 100 EPJ a je na vašom uvážení, kol'ko z týchto peňazí pošlete hráčovi Y.

Pre sumu $a$, ktorú pošlete hráčovi Y, musí platit’: $0 \leq a \leq 100$, a súčasne $a$ je násobkom desiatich.

Suma $a$, ktorú ste mu poslali, bude prenásobená hráčovi Y zhodnotená trojnásobne.

Hráč Y má takto k dispozícii 100 EPJ (svojich) + 3*a (zhodnotený vklad hráča X). Na t’ahu je teraz hráč Y a posiela Vám peniaze spät’ na základe svojho uváženia.

Hráč Y Vám teda môže poslat' spät' sumu $b$, pre ktorú musí platit':

$$
0 \leq b \leq 100+3 * a .
$$

Finálnym ziskom hráča X, teda Vás, bude: $\pi_{a}=100-a+b$.

Finálnym ziskom hráča Y bude: $\pi_{b}=100+3 * a-b$. 
Hráč X

1a) Na začiatku má hráč X 100 EPJ
Hráč Y

1b) Na začiatku má hráč Y 100 EPJ

2) Hráč X sa rozhodne, kol'ko peňazí pošle hráčovi Y. Túto sumu označíme a.

\section{Inštrukcia pre Vás ako hráča $\mathrm{X}$ :}

V tomto kroku vypíšete na hraciu kartičku sumu $a$, ktorú pošlete hráčovi

Hráč X získa od hráča Y sumu $b$.

Na konci má hráč X sumu

$$
100-a+b
$$

Na konci má hráč Y sumu

$100+3 a-b$

\section{$\downarrow$}

3) Hráčovi Y je suma a zhodnotená trojnásobne.

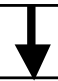

4) Hráč Y sa rozhodne, kol'ko peňazí pošle hráčovi X (môže aj nulu).

Túto sumu označíme $b$.

\section{Inštrukcia pre Vás ako hráča X:}

V tomto kroku sa rozhoduje hráč $\mathrm{Y}$ Vy však v tomto čase môžete porozmýšl'at' (tipnút' si), akú sumu Vám podl'a Vás hráč Y pošle spät'. Toto číslo - odhad $b$ - napíšte na kartičku (Váš „krok 2“). 
Hracia karta HRÁČA X - SENDER/FIRST MOVER

\section{HRÁČ X - SENDER/FIRST MOVER}

KROK 2: V tabulke "SUMA a" zaknúžkujte sumu ktorú ste sa rozhodli poslat hráčovi Y.

\section{SUMA $a$}

\begin{tabular}{|l|l|l|l|l|l|l|l|l|l|l|}
\hline 0 & 10 & 20 & 30 & 40 & 50 & 60 & 70 & 80 & 90 & 100 \\
\hline
\end{tabular}

Stručne prosím vysvetlite, na základe akej úvahy ste zvolili danú sumu

KROK 4: Do kolónky "ODHAD $b$ " uvedite sumu, ktorú Vám podl’a Vás pošle hráč Y spät'.

\section{Kontrolná otázka:}

\section{\begin{tabular}{|l|l|}
\hline ODHAD & $b$ \\
\hline
\end{tabular}}

Ak by Vám hráč Y poslal presne tú sumu, ktonu ste práve uviedli, kol'ko by ste mali peňazí?

D̆alej kartu vypína supervisor!

Hráč Y Vám poslal sumu $b$ ktorej hodnota je:

Váš konečný zisk $=100-a+b=$ 


\section{Inštrukcie pre HRÁČA Y - RECEIVER/SECOND MOVER}

Vážený účastník experimentu, vítame Vás na experimente.

Počas trvania experimentu Vás prosíme nerozprávat' sa alebo inak nekomunikovat' s ostatnými účastníkmi experimentu.

Ako účastníci experimentu ste boli náhodne rozdelení do dvojíc. Každá dvojica je tvorená hráčom X a hráčom Y.

1) Obaja hráči majú na začiatku 100 EPJ (experimentálna peňažná jednotka).

2) Úlohou hráča X, ktorý je na t’ahu ako prvý, je urobit' rozhodnutie, kol'ko peňazí zo 100 $E P J$ (experimentálna peňažná jednotka) chce poslat' hráčovi Y.

3) Tomu sa získaná suma zhodnotí trojnásobne.

4) Po zhodnotení je na t’ahu hráč Y. Jeho úlohou je rozhodnút' sa, akú výšku peňazí vyplatí spät' hráčovi X (môže zvolit' aj nulu).

\section{Celú situáciu si pozrite na obrázku pod textom.}

Obálku, ktorú ste si vytiahli, Vás určila stat' sa hráčom $\boldsymbol{Y}$. Ste teda na t’ahu druhý.

Hráč X (first mover) Vám zo svojej pôvodnej peňažnej zásoby $100 E P J$ zašle sumu $a$, pre ktorú platí $0 \leq a \leq 100$ a súčasne $a$ je násobkom desiatich.

Suma $a$ bude prenásobená multiplikátorom $m$, ktorého hodnota je 3. Táto suma $a * m$ Vám bude pripočítaná k Vašej pôvodnej finančnej zásobe, ktorá na začiatku predstavovala 100 EPJ.

Hráč $\mathrm{Y}$, teda $\mathrm{Vy}$, máte takto $\mathrm{k}$ dispozícii $100 \mathrm{EPJ}+3 * a$. Z týchto peňazí teraz môžete poslat' hráčovi X sumu $b$, pre ktorú platí $0 \leq b \leq 3 * a+100$. Hráč X vie, že ste na začiatku experimentu mali 100 EPJ.

Finálnym ziskom hráča Y, teda Vás, bude: $\pi_{b}=100+3 * a-b$.

Finálnym ziskom hráča X bude: $\pi_{a}=100-a+b$. 
Hracia karta HRÁČA Y - RECEIVER/SECOND MOVER

HRÁC̆ Y - RECEIVER/SECOND MOVER

KROK 2: Do kolónky "ODHAD a" uved te Váš odhad sumy $a$, ktorú Vám pošle hráč $\mathrm{X}$.

\section{\begin{tabular}{|l|l|}
\hline ODHAD $a$ & \\
\hline
\end{tabular}}

Kontrolná otázka:

Ak by Vám hráć $\mathrm{X}$ poslal presne tú sumu, ktorú ste práve uviedli, kolko by ste mali peňazi?

Dalej kartu vypína supervisor!

"SUMA a" ktorú Vám poslal hráč X:

Multiplikátor

$\mathrm{m}=$

$$
m^{*} a=
$$

KROK 4: V kolónke "SUMA $b^{\text {" }}$ uvedte sumu, ktorú zašlete spät hráčovi $\mathrm{X}$ a pre ktorú plati, že je $\mathrm{z}$ intervalu $\left\langle 0,100+m^{*} a\right\rangle$.

Maximálna hodnota sumy $b$ je vo Vašom prípade

\section{SUMA $b$}

Stručne prosím vysvetlite, na základe akej úvahy ste zvolili danú sumu

Dalej kartu vyplňa supervisor!

Váš konečný zisk $=100+m^{*} a-b=$ 